\title{
Pengaruh Latar Belakang Pendidikan Orang Tua Terhadap Hasil Belajar Bahasa Inggris Di Kelas X Smk Swasta Tangerang Selatan
}

\author{
Anggraini $^{1}$; Aspari ${ }^{2}$ 'Desy Tri $^{3}{ }^{3}$ Ani $^{4}$ \\ ${ }^{1}$ Program studi Sistem Informasi Universitas BSI. \\ anggraini.ngg@bsi.ac.id \\ ${ }^{2}$ Program studi Sistem Informasi Universitas BSI. \\ aspari.spa@bsi.ac.id \\ ${ }^{3}$ Program studi Sistem Informasi Universitas BSI . \\ desy.dra@bsi.ac.id \\ ${ }^{4}$ Program studi Administrasi Perkantoran Universitas BSI \\ ani.ark@bsi.ac.id
}

\author{
Cara Sitasi: \\ Anggraini, Aspari, Anggarini, D. T., \& Rakhmanita, A. (2019). Pengaruh Latar Belakang Pendidikan Orang Tua \\ Terhadap Hasil Belajar Bahasa Inggris Di Kelas X Smk Swasta Tangerang Selatan. Wanastra, 11(1), 47-52.
}

\begin{abstract}
The purpose of this research is to know the influence of parents' educational background on the English language skills of vocational students in South Tangerang. The research method used is survey method. Samples of 72 students were randomly selected with a simple random technique. Data collection was done by documentation technique and questionnaire distribution. Data analysis using descriptive analysis and multiple regression analysis. Statistical test using t test and $F$ test. The results showed: (1) there is a significant influence between the parent's student education background simultaneously from English Class X. This is evidenced by the value $F o=28,204$ and Sig. 0,000 <0.05. Contributions provided with parents' parent background variables contribute $45 \%$ to the English proficiency variable. (2) There is a significant influence on the ability of the students of the class X grade in SMK in South Tangerang. This is evidenced by the value of t arithmetic $=2.48$ and Sig. $0.016<0.05$. Variable of parental education background in improving English ability equal to 13,056\%. (3) There is a significant influence on English proficiency. Student class X SMK in South Tangerang. This is evidenced by the value of t arithmetic $=4.881$ and Sig. 0,000<0.05.
\end{abstract}

Keywords: Parents'educationalbackground, English. Knowledge.

\section{PENDAHULUAN}

Pendidikan bagi bangsa yang sedang membangun seperti bangsa Indonesia saat ini merupakan kebutuhan mutlak yang harus dikembangkan sejalan dengan tuntutan pembangunan secara tahap demi tahap. Pendidikan yang dikelola dengan tertib, teratur, efektif dan efisien (berdaya guna dan berhasil guna) akan mampu mempercepat jalannya proses pembudayaan bangsa yang berdasarkan pokok pada penciptaan kesejahteraan umum dan pencerdasan kehidupan bangsa kita sesuai dengan tujuan nasional seperti tercantum dalam alinea IV pembukaan UUD 1945.

Menguasai kemampuan bahasa Inggris sangat penting bagi siswa agar siswa bisa berkomunikasi dengan orang-orang dari negara laindengan mudah, apalagi jika ingin melakukan perjalanan keluar negri, adalah kewajiban bagi mereka untuk bisa berkomunikasi (Saputra, 2015)
Keberhasilan mengajar dalam belajar bahasa Inggris sebagian besar ditentukan oleh penguasaan empat kemampuan bahasa mereka; mendengarkan, berbicara, membaca, dan menulis. Salah satu keterampilan yang paling penting adalah berbicara (Arung, 2016) Berbicara adalah keterampilan yang rumit karena membutuhkan banyak elemen untuk sekaligus digunakan sekaligus (Harliana, 2014).

Peneliti ingin mengadakan penelitian di lembaga pendidikan, apakah latar belakang pendidikan formal orang tua yang tinggi berpengaruh terhadap kemampuan berbicara bahasa Inggris siswa. Untuk mencapai suatu tujuan diperlukan adanya sarana belajar yang memadai, pemenuhan belajar yang sangat penting bagi siswa untuk mengejar prestasi, lingkungan tempat tinggal dan adanya dorongan internal yang muncul dari dalam diri anak sehingga timbul suatu kebiasaan pada diri anak, hal itu merupakan pengaruh dasar dari orang tua apalagi pengaruh Religi pada diri anak yang sangat 
mendarah daging begitupun pengaruh eksternal yang sangat berpengaruh terhadap kemampuan berbicara bahasa Inggris siswa tersebut.

Hakekatnya sangat berbeda sekali orangtua yang berpendidikan tinggi dengan orang tua yang berpendidikan rendah yang pasti kelihatan dalam pengaplikasiannya seorang anak dalam kehidupan perilaku sehari-hari, (Lee, 2011) orang tua yang berpendidikan tinggi mereka pasti lebih tahu dan mengerti cara mendidik dan mengarahkan anaknya, mereka mampu memberikan respon yang tepat dan pengasuhan yang efektif dan mengasyikkan terhadap anaknya (Setyo, 2014). Melalui tercapainya sarana belajar yang memadai, lingkungan tempat tinggal terutama keluarga, minat belajar siswa dan latar belakang pendidikan formal orang tua yang berbeda, semua akan berpengaruh terhadap pencapaian hasil belajarnya terutama kemampuan berbicara bahasa Inggris siswa yang sangat diharapkan orang tua.

Kemampuan berbicara bahasa Inggris siswa tersebut dipengaruhi oleh banyak faktor, diantaranya faktor internal yang timbul dari anak itu sendiri dan faktor eksternal yang timbul diluar pribadinya terutama orang tua sangat berpengaruh dalam pencapaian prestasi anak-anaknya. Proses kemampuan berbicara bahasa inggris siswa ditentukan oleh banyak faktor, seperti faktor manusia berupa latar belakang pendidikan orangtua dan anak didik itu sendiri, dan faktor non manusia seperti kurikulum, media belajar, metode, sarana dan perlengkapan belajar, gaya belajar siswa, serta faktor penunjang lainnya (Adnyani, 2016) Akan tetapi dari sekian banyak faktor tersebut diatas, faktor manusialah yang paling banyak memiliki peran dalam menentukan berhasil tidaknya pendidikan, yang dalam hal ini adalah kemampuan hasil belajar bahasa Inggris siswa. Oleh karena itu pengembangan sumber daya manusia perlu ditata dan dikelola dengan sebaik-baiknya.

Bukan hal yang fiktif lagi seorang anak yang memiliki kemampuan berbicara bahasa inggris dan meraih nilai tinggi di setiap catatan buku laporan hasil belajar di sekolahnya, itu karena persepsi atas latar belakang pendidikan orang tua dan gaya belajar sangatlah besar.Namun kenyataannya tidak semua anak memiliki persepsi atas latar belakang pendidikan orang tua yang besar untuk belajar, dengan kata lain persepsi atas latar belakang pendidikan orang tua yang dimiliki anak berbeda (cowan, 2011).

Berdasarkan pada pemikiran di atas, maka penulis merasa perlu melakukan penelitian tentang pengaruh latar belakang pendidikan orang tua terhadap kemampuan Mata pelajaran Bahasa nggris dengan Judul "Pengaruh Latar Belakang Pendidikan Orang Tua Terhadap Kemampuan Mata Pelajaran Bahasa Inggris (Hasil Belajar Bahasa

\section{Inggris) Siswa Kelas $X$ SMK Swasta Di Tangerang Selatan".}

Penelitian ini difokuskan untuk mengetahui seberapa signifikankah pengaruh latar belakang pendidikan orang tua terhadap hasil belajar siswa khususnya mata pelajaran bahasa inggris.

\section{METODOLOGI PENELITIAN}

\section{A. Populasi dan Sampel}

\section{Populasi}

Menurut (Sugiono, 2002) populasi adalah wilayah generalisasi yang terdiri dari objek atau subjek yang menjadi kuantitas dan karakteristik tertentu yang di tetapkan oleh peneliti untuk dipelajari dan kemudian ditarik kesimpulan. Sementara itu (Arikunto, 1997) menjelaskan bahwa populasi adalah keseluruhan subjek penelitian. Sementara (Margono, 2003) mengatakan bahwa populasi adalah keseluruhan data yang menjadi perhatian didalam suatu ruang lingkup dan waktu yang sudah ditentukan.

\section{Sampel dan teknik pengambilan sampel}

Sampel adalah sebagian dari populasi yang menjadikan responden. Menurut (Winarno, 1982), untuk menentukan besar kecilnya sampel tidak ada ketentuan mutlak. Yang menjadi sampel dalam penelitian ini, sebanyak 72 orang siswa-siswi kelas X SMK Tangerang Selatan. Penentuan sampel ini mengacu pada pendapat Suharsini (Arikunto, 1997) yaitu bahwa apabila objek penelitian lebih besar dari 100 responden diambil $10 \%$ sampai $15 \%$ atau $20 \%$ sampai dengan $30 \%$ tetapi apabila kurang dari 100 responden, maka responden atau sampel diambil seluruh. Dari pernyataan diatas, maka teknik pengambilan sampel dilakukan simple random sampling dengan ketentuan harus siswa-siswi kelas X SMK Swasta Tangerang Selatan. Jumlah sampel yang dilibatkan dalam penelitian adalah 72 siswa (15\% dari populasi).

\section{B. Teknik Pengumpulan Data}

Teknik pengumpulan data yang digunakan dalam penelitian ini adalah Angket atau kuesioner, Menurut (Arikunto, 1997) kuesioner adalah sejumlah pertanyaan tertulis yang di gunakan dalam arti laporan tentang pribadinya, atau hal-hal yang ia ketahui.

Instrumen PenelitianInstrumen atau alat yang dipergunakan dalam upaya pengumpulan data penelitian ini adalah model kuesioner (angket) yang disusun menurut model skala likert. Instrumen dibuat dengan 4 pilihan, yaitu SS (sangat setuju), S 
(setuju), TS (tidak setuju), dan STS (sangat tidak setuju). Adapun tahapan-tahapan pembuatan instrumen ini dimulai dari penentuan variabel, indikator variabel, pembuatan kisi-kisi dan terakhir adalah mengubah kedalam bentuk pernyataanpernyataan.

Table 1: Kisi-kisi Intrumen

\begin{tabular}{lllll}
\hline $\mathrm{N}$ & Variab & Indikator & Nomor & Jum \\
$\mathrm{o}$ & el & & butir & lah \\
& & & buti \\
& & & $\mathrm{r}$
\end{tabular}

\begin{tabular}{|c|c|c|c|c|}
\hline \multirow[t]{10}{*}{1} & \multirow{10}{*}{$\begin{array}{l}\text { Kema } \\
\text { mpuan } \\
\text { Mata } \\
\text { Pelajar } \\
\text { an } \\
\text { bahasa } \\
\text { Inggris } \\
\text { siswa }\end{array}$} & Aktivitas & \multirow{10}{*}{$\begin{array}{l}\text { Variabe } \\
1 \quad \text { ini } \\
\text { diukur } \\
\text { melalui } \\
\text { tes } \\
\text { dengan } \\
\text { skala } \\
\text { skor } 10 \\
-100\end{array}$} & \\
\hline & & melakukan & & \\
\hline & & berbicara, & & \\
\hline & & $\begin{array}{l}\text { Membaca, dan } \\
\text { mendengarkan }\end{array}$ & & \\
\hline & & Tingkat & & \\
\hline & & kesalahan & & \\
\hline & & mengucapkan & & \\
\hline & & $\begin{array}{l}\text { kata, } \\
\text { membaca, dan } \\
\text { mendengarkan }\end{array}$ & & \\
\hline & & $\begin{array}{l}\text { Pencapaian } \\
\text { target }\end{array}$ & & \\
\hline & & $\begin{array}{l}\text { Keberanian } \\
\text { berbicara, } \\
\text { membaca, dan } \\
\text { mendengarkan }\end{array}$ & & \\
\hline \multicolumn{5}{|c|}{ Jumlah } \\
\hline \multirow[t]{6}{*}{3} & \multirow{6}{*}{$\begin{array}{l}\text { Pengar } \\
\text { uh latar } \\
\text { belaka } \\
\text { ng } \\
\text { pendidi } \\
\text { kan } \\
\text { orang } \\
\text { tua }\end{array}$} & $\begin{array}{l}\text { Penguasaan } \\
\text { bahasa Inggris }\end{array}$ & $1,2,3$ & 3 \\
\hline & & Kemampuan & $4,5,6$ & 3 \\
\hline & & $\begin{array}{l}\text { komunikasi } \\
\text { dengan anak }\end{array}$ & & \\
\hline & & $\begin{array}{l}\text { Membimbing } \\
\text { anak }\end{array}$ & $7,8,9$ & 3 \\
\hline & & $\begin{array}{l}\text { Memberikan } \\
\text { dukungan }\end{array}$ & $\begin{array}{l}10,11,1 \\
2\end{array}$ & 3 \\
\hline & & $\begin{array}{l}\text { Memberikan } \\
\text { motivasi }\end{array}$ & $\begin{array}{l}13,14,1 \\
5\end{array}$ & 3 \\
\hline
\end{tabular}

Sumber: Anggraini dkk (2018)

\section{Kalibrasi}

Untuk mengetahui sejauh mana butir-butir instrumen mewakili apa yang akan diukur dari masing-masing variabel yang diteliti, tentu diperlukan uji instrument terlebih dahulu. Uji coba instrument ini dilaksankan untuk mengetahui validitas (kesahihan) dan reabilitas (keterandalan) suatu intrument, agar dapat diterima sebagai instrument penelitian. Instrumen dikatakan valid apabila mampu mengukur apa yang hendak diukur. Sedangkan reabilitas mengacu pada konsistensi hasil evaluasi Kalibrasi kemampuan berbicara bahasa Inggris siswa dalam penelitian ini menjawab pertanyaan dalam bentuk pilihan ganda dengan lima opsi. Dalam hal ini siswa cukup memilih salah satu jawaban yang telah disediakan dan dianggap paling tepat

Kalibrasi instrument kemampuan bahasa Inggris menjawab pertanyaan dari pilihan ganda akan mendapat nilai 1 (satu): benar diberi nilai satu, dan begitu pun sebaliknya apabila menjawab pertanyaan salah maka mendapat nilai 0 (nol): salah diberi nilai nol.

\section{a. Validitas butir}

Instrument kemampuan dalam mata pelajran bahasa Inggris (hasil belajar) berupa pernyataan terdiri dari 40 butir pernyataan. Validitas butir instrument ditentukan dengan membandingkan antara besaran $r$ xy yang diperoleh dengan harga kritis $r$ pearson's product moment pada $\mathrm{N}=35$. Jika $\mathrm{r}$ hitung $>\mathrm{r}$ tabel, maka butir tersebut tidak valid dan selanjutnya digunakan untuk pengumpulan data. Sebaliknya, jika $r$ hitung < $r$ tabel, maka butir tersebut tidak valid dan selanjutnya tidak digunakam dalam penelitian. Dalam tabel harga kritis $\mathrm{r}$ tabel pearson's product moment diketahui 0.334 untuk $\mathrm{N}=35$ dengan 0.05 . uji validitas instrument kemampuan dalam mata pelaran (hasil belajar) bahasa Inggris dilakukan dengan bantuan SPSS versi 22 for windows.

\section{b. Reabilitas Instrumen}

Reabiltas terhadap butir-butir instrumen kemampuan berbicara bahasa Inggris siswa yang valid dianalisis dengan teknik Alpha Cronbach. Penghitungan koefisien reabilitas intrument dilakukan setelah butir yang tidak valid tidak digunakan dalam penelitian sehingga tidak diperhitungkan dalam penelitian ini, penghitungan dilakukan dengan menggunakan bantuan program SPSS 22 for windows.

\section{Teknik Analisis Data}

\section{Analisis Deskriptif}

Setelah data terkumpul peneliti melakukan tabulasi dan menganalisa jawaban dari instrument. Tabulasi data mengunakan SPSS Versi 2.2 for windows. Dalam menganalisa deskripsi akan diperoleh tabel frekuensi data grafik polygon, dan histogram dari variabel. Lebih lanjut, setiap kelompok data akan di proses dan dianalisis untuk mengukur tendensi sentral dan nlai rata-rata, median, varian,standar deviasi dan kurtosis mengunakan SPSS versi 2,2 for windows.

\section{2 .Pengujian Persyaratan Analisis}

a. Uji Normalitas 
Untuk mengetahui persyaratan pengujian hipotesis, maka di gunakan pengujian normalitas sampel dimana untuk mengetahui apakah semua variabel penelitian mengikuti distribusi normal. Pengujian normalitas sampel dalam penelitian ini dilakukan dengan uji kolmogorov-smirnov (KS) dengan taraf signifikan $\square=0.05$; dengan kriteria jika nilai sig $>$ 0.05; maka data tidak berdistribusi normal.

\section{b. Uji Multikolineritas}

Uji multikolineritas bertujuan untuk menguji apakah model regresi ditemukan adanya korelasi yang sempurna antar variabel bebas (independen). Model regresi yang baik seharusnya tidak terjadi korelasi yang sempurna diantara variabel bebas. Salah satu cara untuk mendeteksi adanya multikolinearitas adalah dengan melihat tolerance atau variance inflantion factor (VIF). Apabila tolerance lebih kecil dari 0,1 atau nilai VIF diatas 10, maka terjadi multikolineritas. Aturan berikutnya adalah jika nilai tolerance dan VIF mendekati angka 1 maka dalam analisis regresi ganda tidak ada multikolinearitas.

\section{c. Uji Heteroskesdastiditi}

Pengertian tentang heteroskesdastisitas adalah apabila kesalahan atau residual yang diamati tidak memiliki varian yang konsta. Salah satu metode untuk menunjukan heterosdastisitas adalah dengan membuat scatter plot antara standardized Residual (ZRESID) dan standardized Predicted (ZPRED).

\section{Teknik Pengujian Hipotesis}

Teknik Analisis data yang penulis gunakan adalah regresi ganda (mengunakan program SPSS), Analisis regresi ganda adalah semua alat analisis peramalan nilai pengaruh variabel bebas terhadap satu variabel terikat, untuk membuktikan ada atau tidaknya pengaruh antara variabel bebas dengan variabel terikat. Dalam prakteknya proses perhitungan dilakukan dengan SPSS. Prosedur pengujiannya adalah sebagai berikut.

\section{Pengujian Signifikan Garis Regresi}

Hasil pengujian signifikan garis regresi dilihat dari output program SPSS melalui analisis PadaTable 2 dibawa ini.

Table 2: Table data Anova

\begin{tabular}{llllll}
\hline ANOVA & & & & \\
\hline Model & Sum of & d & Mean & F & Sig. \\
& & f & Square & & \\
& Squares & & & \\
\hline \multicolumn{2}{l}{ gressionR } \\
e & & & & \\
\hline 1 & esidualR & & & & \\
\hline
\end{tabular}

\begin{tabular}{l}
\hline Total \\
\hline $\mathrm{X},($ Constant):Predictors .a, \\
\hline $\mathrm{Y}$ :Variabel Dependent .b \\
\hline Sumber: Anggraini dkk (2018)
\end{tabular}

Kriteria Signifikansinya adalah:

Jika digunakan kolom Sig, maka kriteria signifikansinya adalah:

Kriteria signifikansinya adalah:

“ jika sig $>0,05$ maka koefisian regresi tersebut signifikan".Jika digunakan kolom F, maka kriteria signifiaknsinya adalah

“ jika $\mathrm{F}$ hitung $>\mathrm{F}$ tabel maka koefisien regresi tersebut signifikan".

$\mathrm{T}$ tabel dipilih sesuai dengan ketentuan pengujian statistik pada distribusi $\mathrm{F}$, yaitu taraf nyata derajat $(\mathrm{dk})$ pembilang $=\mathrm{k}$ dan derajat $(\mathrm{dk})$ penyebut $=\mathrm{n}-\mathrm{k}-1$, dimana $\mathrm{n}$ adalah banyaknya anggota sampel dan $\mathrm{k}$ adalah banyaknya variabel bebas.

\section{HASIL DAN PEMBAHASAN}

\section{A.Deskripsi Data}

\section{DataKemampuan berbicara bahasa Inggris(Y)}

Data kemampuan mata pelajaran (hasil belajar) bahasa Inggris diperoleh dari dari kuisioner yang di jawab oleh 72 siswa. Skor yang di peroleh adalah terendah 63, skor tertinggi 98, skor ratarata sebesar 80,99, median sebesar83, modus sebesar 83 dan simpangan baku sebesar 8,828 .

Tabel3: Deskripsi Kemampuan Mata Pelajaran (hasil belajar) bahasa Inggris

\begin{tabular}{lcc}
\multicolumn{3}{c}{ Statistics } \\
\hline \multicolumn{2}{c}{ Kemampuan Mata Pelajaran } & Bahasa Inggris \\
\hline \multirow{2}{*}{$\mathrm{N}$} & Valid & $\mathbf{7 2}$ \\
\cline { 2 - 3 } & Missing & $\mathbf{0}$ \\
\hline Mean & $\mathbf{8 0 , 9 9}$ \\
\hline Median & $\mathbf{8 3 , 0 0}$ \\
\hline Mode & $\mathbf{8 3}$ \\
\hline Std. Deviation & $\mathbf{8 , 8 2 8}$ \\
\hline Minimum & $\mathbf{6 3}$ \\
\hline Maximum & $\mathbf{9 8}$ \\
\hline
\end{tabular}

Sumber: Anggraini dkk (2018)

Bila dilihat dari hasil perhitungan di atas, maka bisa dikatakan bahwa kemampuan mata pelajaran bahasa Inggris siswa kelas X SMK Swasta di Tangerang Selatan adalah baik. Hal ini diindikasikan dengan perolehan nilai rata-rata sebesar 80,99. 


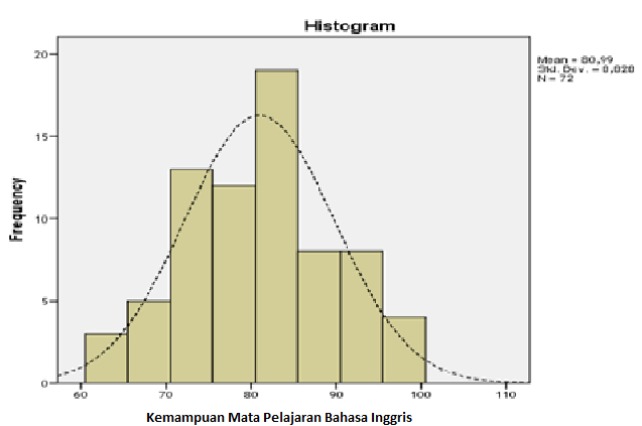

Sumber: Anggraini dkk (2018)

Gambar 2: Histogram Variabel Kemampuan Mata Pelajaran bahasa Inggris

Dari histogram dan polygon frekuensi di atas dapat disimpulkan bahwa data kemampuan mata pelajaran bahasa Inggris siswa kelas X SMK Swasta Tangerang Selatan memiliki sebaran yang normal.

2. Data Persepsi atas latar belakang pendidikan orang tua $(\mathrm{X})$

Data latar belakang pendidikan orang tua diperoleh dari kuisioner yang di jawab oleh 72 siswa dihasilkan skor terendah 29 , skor tertinggi 73 , skor rerata sebesar 51,93, median 53, modus sebesar 49, dan simpangan baku sebesar 8,436 Tabel 4 . Deskripsi data Penelitian Persepsi atas Latar Belakang Pendidikan orang tua

Table 4: Pengaruh persepsi latar belakang orang tua

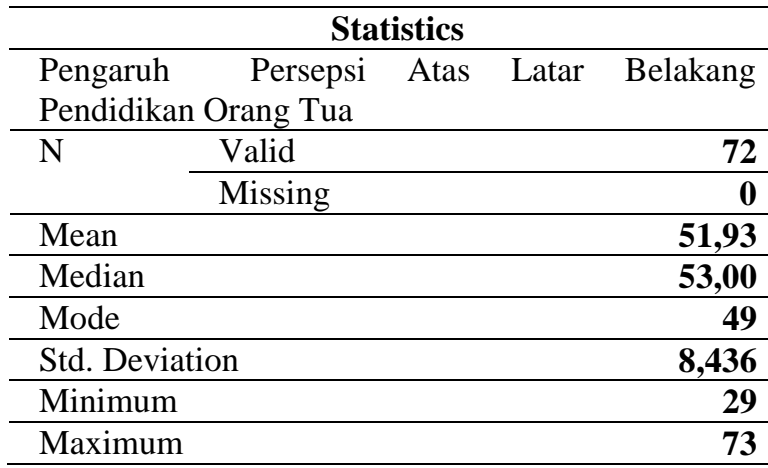

Sumber: Anggraini dkk (2018)

Dari hasil perhitungan di atas, maka bisa dikatakan bahwa pengaruh latar belakang pendidikan orang tua siswa kelas X SMK Swasta Tangerang Selatan cukup baik. Hal ini di indikasikan dengan perolehan skor rerata sebesar 51,93 mendekati nilai mediannya.

Untuk memperjelas data di atas, digambarkan dalam histogram sebagai berikut

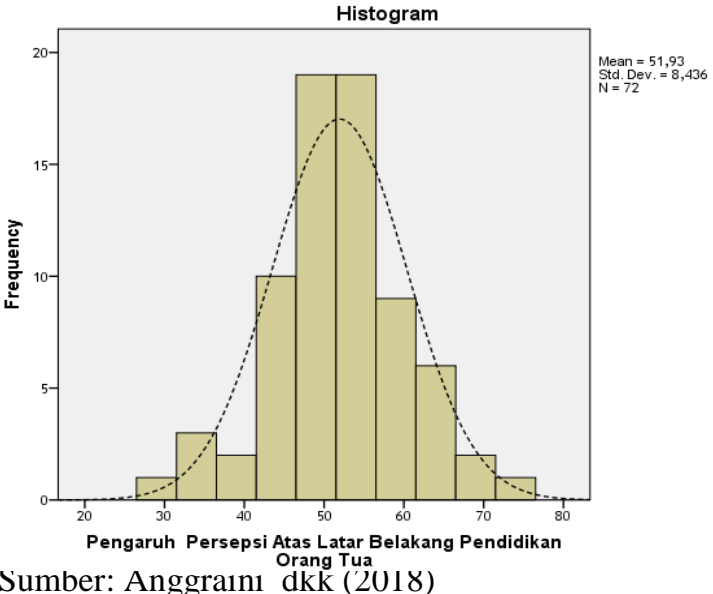

Gambar 3: Persepsi atas latar belakang pendidikan orang tua

Dari histogram dan polygon frekuensi di atas dapat disimpulkan bahwa latar belakang pendidikan orang tua siswa kelas X SMK Swasta Tangerang Selatan memiliki sebaran yang normal.

\section{B. Uji Persyaratan Analisis Regresi}

\section{Uji Asumsi Klasik}

\section{a. Uji Multikolinearitas}

Uji multikolinieritas bertujuan untuk menguji apakah model regresi ditemukan adanya korelasi yang sempurna antar variabel bebas (independent). Model regresi yang baik seharusnya tidak terjadi korelasi yang sempurna diantara variabel bebas. Salah satu cara untuk untuk mendeteksi adanya multikolinieritas adalah dengan melihat tolerance atau varian inflation factor (VIF). Apabila tolerance $<0,1$ atau nilai $\mathrm{VIF}>10$ maka terjadi multikolinearitas.

Table 6Uji Multikolinearitas

\begin{tabular}{|c|c|c|}
\hline \multicolumn{3}{|l|}{ Coefficients $^{\mathrm{a}}$} \\
\hline \multirow[t]{2}{*}{ Model } & \multicolumn{2}{|c|}{ Collinearity Statistics } \\
\hline & Tolerance & VIF \\
\hline $1 \quad$ (Constant) & & \\
\hline persepsi atas & ,747 & 1,338 \\
\hline $\begin{array}{l}\text { latar belakang } \\
\text { pendidikan } \\
\text { orang tua }\end{array}$ & & \\
\hline
\end{tabular}

Sumber: Anggraini dkk (2018)

Hasil uji multikolininearitas pada tabel di atas diketahui bahwa hasil Tolerance 0,747> 0,1 atauvarian inflation factor $(\mathrm{VIF}) 1,338<10$. Sehingga dapat dinyatakan bahwa tidak ada multikolinearitas 
terhadap persepsi latar belakang pendidikan orang tua siswa pada analisis regresi ini. sumbu Y. Hal ini menunjukkan bahwa tidak terjadi heteroskedastisitas pada model regresi tersebut, sehingga dapat dipakai untuk memprediksi variabel kemampuan mata pelajaran bahasa Inggris berdasarkan persepsi atas latar belakang pendidikan orang tua.

\section{KESIMPULAN}

Pada bagian kesimpulan ini, penulis uraikan secara singkat hasil penelitian yang diperoleh di lapangan dapat ditarik simpulan sebagai berikut; 1)Terdapat pengaruh yang signifikan latar belakang pendidikan orang tua terhadap kemampuan mata pelajaran bahasa Inggris siswa kelas X SMK Swasta Tangerang Selatan. Hal ini dibuktikan dengan perolehan nilai $\mathrm{Fo}=28,204$ dan Sig. 0,000 < 0,05. Kontribusi yang diberikan variabel latar belakang pendidikan orang tua memberikan kontribusi sebesar $45 \%$ terhadap variabel kemampuan mata pelajaran bahasa Inggris. 2)Terdapat pengaruh yang signifikan latar belakang pendidikan orang tua terhadap kemampuan mata pelajaran bahasa Inggris Siswa kelas X SMK Swasta Tangerang Selatan. Hal ini dibuktikan dengan perolehan nilai thitung $=2,48$ dan Sig. $0,016<0,05$. Variabel latar belakang pendidikan orang tua dalam meningkatkan kemampuan berbicara bahasa Inggris sebesar 13,056 $\%$.

\section{REFERENSI}

Anggraini \& Aspari. (2018). Laporan Akhir Penelitian Mandiri.

Adnyani, I. K. (2016). Motivasi dan sikap bahasa mahasiswa jurusan pendidikan bahas Inggris Undiksha. Research Gate , 2303-288x.

Arikunto, S. (1997). prosedur penelitian suatu pendekatan praktek. Jakarta: Rineka cipta.

Arung, F. (2016). improving student's speaking skill trought debate technique. journal of English Education , 2502-6909.

cowan, p. a. (2011). parenting and the child's world influences on academic, intellectual, and social-emotional development. research gate

Harliana, S. (2014). Problem of teaching speaking for private SMA in Malang,research gate journal.

Lee, J. (2011). The effect of parent's academic background on children's academic achievement. Research gate .
Margono. (2003). metodologi penelitian pendidikan. Jakarta: Tineka cipta.

Saputra, J. B. (2015). communivative language teaching:changing students' speaking skill. premise Journal , 2442-482x.

Setyo, a. (2014). jurnal ilmiah pendidikan bimbingan konseling.

Sugiono. (2002). statistik untuk penelitian. Bandung: cv Alfabeta.

Winarno, S. (1982). pengantar penelitian ilmiah. Bandung: Tarsito.

\section{Profil Penulis}

\section{Penulis 1}

Anggraini,M.Pd lahir di Sawahlunto, 19 December 1985.lulusan dari STKIP Kusuma Negara Jakarta Progra studi Pendidikan Bahasa Inggris and Pasca Sarjana Universitas Indraprasta PGRI Jakarta Program Magister Pendidikan Bahasa Inggris. Sudah mengajar selama 10 tahun. Sekarang aktif sebagai dosen di UBSI Bogor dari sejak 2010 sampai sekarang.

\section{Penulis 2}

Aspari, SS., M.Pd. lahir di Sumenep, 17 Januari 1980. Lulusan Diploma Tehnik Informatika MAGMA Malang tahun 2001, S1 Jurusan Sastra Inggris dari STBA Nusamandiri, dan S2 Pendidikan Bahasa Inggris di Universitas Indraprasta PGRI Jakarta. Pengalaman mengajar sudah lebih dari 17 Tahun. Dan aktif sebagai Dosen di UBSI Bogor dari sejak tahun 2010 sampai sekarang.

\section{Penulis 3}

Desy Tri Anggarini, SE, MM. lahir di Semarang, 25 Desember 1978. Lulusan S1 Fakultas Ilmu Ekonomi Studi Pembangunan Universitas Diponegoro Semarang dan S2 Magister Manajemen Universitas Trisakti Jakarta. Mengajar di Universitas BSI sejak 2011 sampai sekarang.

\section{Penulis 4}

Ani Rakhmanita, SE, MM. lahir di Jakarta, 26 Juli 1981. Lulusan S1 Fakultas Ilmu Ekonomi Akuntansi Universitas Krisna Dwiapayana dan S2 Magister Manajemen Universitas BSI Bandung. Mengajar di Universitas BSI sejak 2007 sampai sekarang. 